\title{
Detection and Molecular Characterization of Cronobacter sakazakii Isolated from Powdered Infant Formula (PIF) from North Central Region, Nigeria
}

\author{
Simon I. Enem ${ }^{1}$, Chidozie O. Ogbu1, Chinwe E. Okoli1, Ene Godwin'1, Gabriel K. Omeiza1, \\ Pascal U. Umeakuana ${ }^{2}$, Wesley D. Nafarnda ${ }^{1}$ \\ ${ }^{1}$ Department of Veterinary Public Health and Preventive Medicine, University of Abuja, Abuja, Nigeria \\ ${ }^{2}$ Departments of Veterinary Medicine, Faculty of Veterinary Medicine, University of Abuja, Abuja, Nigeria \\ Email: *simon.enem@uniabuja.edu.ng
}

How to cite this paper: Enem, S.I., Ogbu, C.O., Okoli, C.E., Godwin, E., Omeiza, G.K., Umeakuana, P.U. and Nafarnda, W.D. (2020) Detection and Molecular Characterization of Cronobacter sakazakii Isolated from Powdered Infant Formula (PIF) from North Central Region, Nigeria. Advances in Microbiology, 10, 307-317. https://doi.org/10.4236/aim.2020.107022

Received: April 29, 2020

Accepted: July 17, 2020

Published: July 20, 2020

Copyright $\odot 2020$ by author(s) and Scientific Research Publishing Inc. This work is licensed under the Creative Commons Attribution International License (CC BY 4.0).

http://creativecommons.org/licenses/by/4.0/

\begin{abstract}
Cronobacter sakazakii is an emerging ubiquitous and opportunistic pathogen that currently contaminates a wide spectrum of foods including powdered milk and poses a lethal threat to neonates, the elderly and persons with immune deficiencies. They cause life threatening neonatal meningitis, septicemia, and necrotizing enterocolitis. A total of 360 samples of powdered infant formula were collected from postnatal hospital attendees reconstituting the PIF for their children in the North Central region of Nigeria where cases of infant mortality are very high and presenting as enterocolitis and diarrhea. Pre-enriched samples were cultured in chromogenic Cronobacter broth and were then further sub-cultured into a chromogenic Cronobacter sakazakii agar. They were positive, exhibiting yellowish cultures typical of Cronobacter sakazakii. Biochemical tests of the isolates were also carried out and indicated the presence of Cronobacter sakazakii. The isolates were then characterized molecularly using specie specific PCR detection of Cronobacter sakazakii. The targeted genes of interest were ompA gene and $C P A$ gene. The isolates tested showed bands for omp $A$ gene on electrophoresis imager and were confirmed as Cronobacter sakazakii. In Nigeria, majority of infants are still fed with PIF. There is no existing data on the detection of Cronobacter sakazakii previously reported in the North central region of Nigeria hence the need to carry out the present study. The result of the study demonstrated the need for effective prevention and control measures as contamination of PIF with Cronobacter sakazakii constituted potential public health risk to neonates and infants.
\end{abstract}




\section{Keywords}

Detection, Molecular Characterization, Cronobacter sakazakii, Powdered Infant Formula (PIF)

\section{Introduction}

Cronobacter sakazakii is considered an emerging ubiquitous and opportunistic pathogen associated with necrotizing enterocolitis, meningitis, septicemia amongst infants and immunocompromised neonates with 40\% - 80\% mortality rate [1] [2] [3] [4]. In recent times, infection with Cronobacter sakazakii has also been reported in all age groups especially those with immunocompromising conditions and the elderly [5] [6].

The organism is ubiquitous and has been isolated from a wide range of foods and beverages such as meat and meat products, milk, cheese, fermented bread, vegetables, grains, herbs and spices [7] [8] [9] [10] [11] and also recovered from the human gastrointestinal tract and thought like as members of the normal fecal flora [12]. While the primary reservoir of $C$. sakazakii is yet to be defined, plant materials are believed to be the likely source [13]. Powdered infant formula has also been implicated as a vehicle of infection in numerous cases [14].

There have been several reports around the world of the recovery of Cronobacter sakazakii from PIF [7] [15] [16] and also from various sites and equipment in PIF processing facility [17]. Literature review indicated an epidemiologic linkage between contaminated PIF and case of Cronobacter sakazakii infections in infants [1] [15] [18].

Cronobacter sakazakii is gram-negative, rod-shaped, motile and facultative anaerobic bacteria belonging to the family Enterobacteriaceae and was identified as unique species by [19]. The genus Cronobacter has been divided into seven species namely Cronobacter sakazakii, Cronobacter malonaticus, Cronobacter turicensis, Cronobacter muytjensis, Cronobacter dublinesis, Cronobacter universalis and Cronobacter condimenti [20] [21]. The predominant species associated with neonatal infection is Cronobacter sakazakii [22]. Due to the strong ability to resist desiccation environment, $C$. sakazakii strains can persist in PIF for more than one year [23]. There is need to monitor the presence of $C$. sakazakii in commercial PIF [24]. C. condiment was identified as the seventh species recently by [20] and $C$. universalis replaced $C$. gemospecies [24].

Clinical presentations of Cronobacter infections in infants include NEC, bacteremia and meningitis, with case fatality rates ranging between $40 \%$ and $80 \%$ being reported [8] [25]. Infections in older infants have also been noted [25].

Several molecular means, including PCR assays that targeted the gene responsible for a-glucosidase activity (gluA), 16S rRNA gene sequencing and internal transcriber spacer (ITS) sequence between $16 \mathrm{~S}$ and $23 \mathrm{~S}$ rRNA, have been shown to be more reliable method for detection of Cronobacter species [26]. The outer mem- 
brane protein A (ompA) of C. sakazakii plays an important role in invading human intestinal epithelial cells and brain microvascular endothelial cells [27] [28]. The sequence analysis of $\operatorname{omp} A$ gene has been applied to identify and type this pathogen for purposes of pathogenicity [27] [29]. Furthermore, $r p o B$ allele sequence is also included in the international PubMLST database [24]. Therefore, a comprehensive comparative analysis of $C$. sakazakii strains isolated from PIF using MLST, O-antigen serotyping, omp $A$ scheme, and $r p o B$ scheme is warranted [24].

\section{Materials and Methods}

\subsection{Study Area}

Nigeria is divided into six geo-political zones. The study was carried out in the North Central zone comprising of six states namely Niger, Kogi, Nassarawa, Benue, Kaduna and Plateau states and Abuja FCT.

\subsection{Study Design}

The work was a cross sectional epidemiological study and a multi-staged sampling method was adopted. In the first place, a simple random sampling by balloting was used to select 3 out of the states in the North Central zone of Nigeria namely Abuja FCT, Nasarawa and Kogi states. Simple random sampling was also used to select 2 out of the selected major hospitals in each of the states. Systematic sampling method was then used to select one out of every five mothers coming for postnatal hospital examination.

\subsection{Sample Collection and Isolation}

Samples were collected under aseptic conditions and transported to Peak Laboratory Limited, Gwagwalada, Abuja where the initial analysis was carried out. A total of 360 samples of powdered infant formula were collected from nursing mothers attending postnatal hospital examination in the three of the six North Central states of Nigeria (Nasarawa-142; Abuja-98; Kogi-120).

A modified version of ISO/TS 22964 [30] method was used in the isolation of bacteria. An enrichment media of buffered peptone water (BPW) supplemented with $8 \mathrm{mg} /$ litre vancomycin $10 \mathrm{mg} /$ litre cefsulodin and $0.05 \mathrm{mg} /$ litre cefixine (BPW-VCC) was prepared to suppress the growth of gram positive organisms, Aeromonas and Proteus spp. [31]. A total of $25 \mathrm{~g}$ of sample was mixed with the pre-enrichment medium of buffered peptone water (BPW) and incubated at $37^{\circ}$ for about $20 \mathrm{~h}$. This was followed by a transfer of $0.1 \mathrm{ml}$ of the pre-enriched culture to Cronobacter screening broth (Oxoid, UK) [32] and incubated at $42^{\circ}$ for $24 \mathrm{~h}$. The positive samples which showed yellowish-white colouration were then streaked on chromogenic Cronobacter sakazakii agar and incubated at $37^{\circ} \mathrm{C}$ for $24 \mathrm{~h}$. The isolates that showed yellowish colouration were further subjected to the following biochemical tests-indole production, catalase test, oxidase production, methyl red, Voges-Proskauer and acid production with nucitol. 


\subsection{DNA Extraction}

Presumptive Cronobacter isolates were later incubated overnight at $37^{\circ} \mathrm{C}$ in Luria Bertani broth. Genomic DNA was extracted using a Genomic DNA isolation kit (Zymos, USA) according to the manufacturer's instructions. Concentration and purity of DNA samples were estimated by Nanodrop 2000 (Thermo Scientific, USA).

\subsection{Molecular Characterization}

The molecular characterization of the positive isolates was carried out at the West African Centre for Cell Biology of Infectious Pathogens (WACCBIP), University of Ghana. The DNAs from the positive isolates were first extracted using Zymos test kits according to manufacturer's specifications. Amplification of 16S rRNA specific for Cronobacter species was carried out using conventional PCR.

PCR using a hot start Taq polymerase for the identification of Cronobacter sakazakii by the amplification of $c p a A$ gene and the virulence associated genes of the outer membrane protein $\mathrm{A}(\operatorname{omp} A)$ was carried out. The following two specie specific primer sets for Cronobacter sakazakii were commercially procured (Inqaba Biotec, South Africa) and used for the PCR (Table 1). For a $100 \mu \mathrm{M}$ stock solution of the Forward and Reverse $C P A$ primers, $588.31 \mu \mathrm{l}$ and $543.34 \mu \mathrm{l}$ of water were added respectively. Also for the Forward and Reverse $\operatorname{omp} A$ primers, $554.58 \mu \mathrm{l}$ and $516.66 \mu \mathrm{l}$ of water were added respectively. The PCR cycling conditions consisted of an initial denaturing step at $95^{\circ} \mathrm{C}$ for $8 \mathrm{~min}$ and a second denaturing at $95^{\circ} \mathrm{C}$ for $30 \mathrm{~s}$, followed by 30 cycles of $58^{\circ} \mathrm{C}$ for $30 \mathrm{~s}$, extension at $72^{\circ} \mathrm{C}$ for $30 \mathrm{~s}$, followed by a final $7 \mathrm{~min}$ extension step at $72^{\circ} \mathrm{C}$. Another $4^{\circ} \mathrm{C}$ was added for the end of PCR and for keeping the samples till removal and storage. The PCR results were subjected to gel electrophoresis using $1.5 \%$ agarose gels and were visualized with ethidium bromide $(\mathrm{EtBr})$ using a computer imager.

\section{Results}

Of the 360 samples analyzed, 16 tested positive after cultural examination as presented in Table 2.

The positive samples were further confirmed to be Cronobacter specie using biochemical tests (Table 3 ).

The two genes of interest (GoI) typed in this study were $C P A$ and $\operatorname{omp} A$ genes. Only the ompA gene showed clear bands on agarose gel (Figure 1).

An image of the Agarose gel result post electrophoresis following amplification

Table 1. Specific primers for identification of Cronobacter sakazakii.

\begin{tabular}{cccc}
\hline Primer name & Primer sequence (5'-3') & Barcode & Length \\
\hline \multirow{2}{*}{ ompA } & F (ompA) TCAAAGCTCAGGGCGTACAG & S3CE9 & 20 bases \\
& R (ompA) ACCCTGGTTGTAAGCGTCAG & S3CEA & 20 bases \\
CPA & F (cpA) GACAACCCTGAGTTCTGGTAAC & S3CE7 & 22 bases \\
& R (cpA) ATGCGTATTTCTGCTGGTAA & S3CE8 & 20 bases \\
\hline
\end{tabular}


Table 2. Cultural isolation of Cronobacter species.

\begin{tabular}{cccc}
\hline Sample location & No of samples collected & No positive & \% positive \\
\hline Nasarawa & 142 & 8 & 5.6 \\
Abuja & 98 & 3 & 3.1 \\
Kogi & 120 & 5 & 4.2 \\
Total & 360 & 16 & 4.4 \\
\hline
\end{tabular}

Table 3. Biochemical identification of Cronobacter species.

\begin{tabular}{|c|c|c|c|c|c|c|}
\hline \multirow{2}{*}{$\begin{array}{l}\text { Isolate no \& } \\
\text { Source state }\end{array}$} & \multirow{2}{*}{ Indole } & \multicolumn{5}{|c|}{ Biochemical tests } \\
\hline & & MR & VP & Inocitol & Oxidase & Catalase \\
\hline \multicolumn{7}{|l|}{ Nasarawa } \\
\hline N5 & - & - & + & + & - & + \\
\hline $\mathrm{N} 28$ & - & - & + & + & - & + \\
\hline N37 & - & - & + & + & - & + \\
\hline N76 & - & - & + & + & - & + \\
\hline N78 & - & - & + & + & - & + \\
\hline $\mathrm{N} 82$ & - & - & + & + & - & + \\
\hline $\mathrm{N} 112$ & - & - & + & + & - & + \\
\hline N126 & - & - & + & + & - & + \\
\hline \multicolumn{7}{|l|}{ Abuja } \\
\hline A15 & - & - & + & + & - & + \\
\hline A27 & - & - & + & + & - & + \\
\hline A63 & - & - & + & + & - & + \\
\hline Kogi & & & + & + & & + \\
\hline K9 & - & - & + & + & - & + \\
\hline K22 & - & - & + & + & - & + \\
\hline K46 & - & - & + & + & - & + \\
\hline K51 & - & - & + & + & - & + \\
\hline K85 & - & - & + & + & - & + \\
\hline
\end{tabular}

Key: Indole production, MR-Methyl red, VP-Voges Proskauer, acid production with Inositol, Oxidase and Catalase tests.

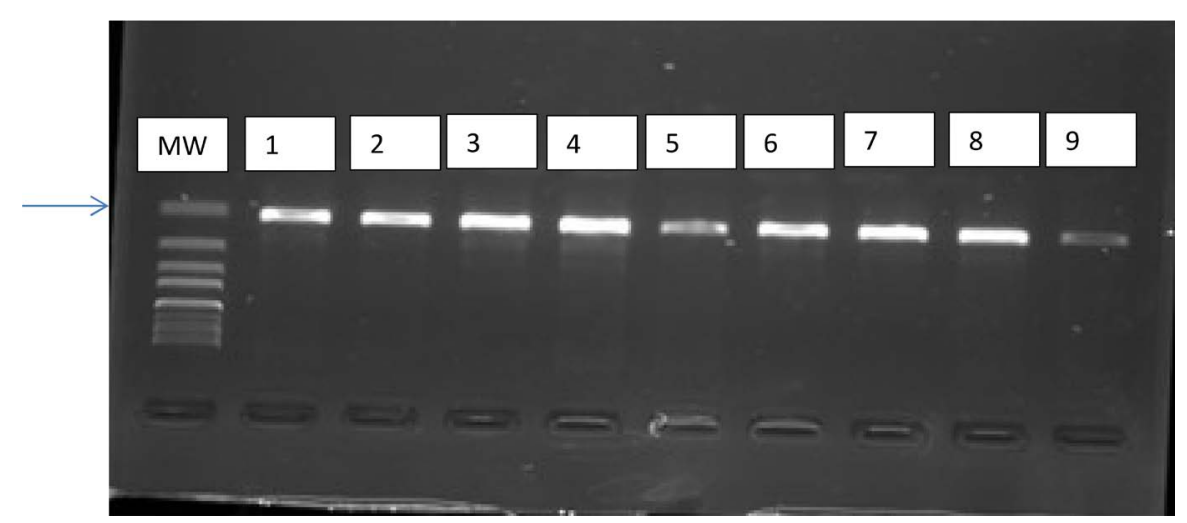

Figure 1. PCR result. 
of ompA gene. Wells were loaded with PCR products from test samples 1 - 10 and positive control. EtBr was added to the gel before electrophoresis to a final concentration of $0.5 \mu \mathrm{g} / \mathrm{l}$ followed by separation at $100 \mathrm{v}$ for $1 \mathrm{hr}$.

\section{Discussion}

Cronobacter infection poses a very high risk to neonates and immunocompromised individuals and proper identification of the organism will provide good understanding of the epidemiology of the infection. Contamination of PIF due to Cronobacter sakazakii has been given serious attention in the developed world [16] [33]. In the developing world and Nigeria in particular, scanty work has been carried out on Cronobacter species [34] [35] [36] hence it needs further investigation. No reported study on C. sakazakii has been carried out in the North Central region of Nigeria where the incidence of meningitis and colitis remains very prevalent.

In the present study, out of the 360 samples analyzed, 16 were positive indicating an average prevalence rate of $4.4 \%$ in the North Central zone of Nigeria. The prevalence rate fell within the range reported in previous studies [37] [24]. The prevalence in this study could be closely compared to the work of [38] $(4.3 \%, 23$ out of 530). The highest prevalence was recorded in Nasarawa state (5.6\%) followed by Kogi state with $4.1 \%$ prevalence and then Abuja showing the least prevalence of $3.1 \%$. The variation in the prevalence rate may be directly proportional to the level of perception of personal hygiene. Abuja is more cosmopolitan inhabiting relatively more educated and civilized members of the public.

The presumptive positive cultures after isolation were equally subjected to biochemical tests for initial confirmation. They all responded to the key biochemical tests for identification of $C$. sakazakii. The isolates were Catalase positive and Oxidase negative. They were negative to Indole and Methyl Red production and positive for Voges Praskaeur. They were all able to produce acid from inocitol. The result is in agreement with the reports by [19] [39] [40]. Inositol fermentation has been proposed recently as a marker of pathogenicity for Cronobacter based on the presence of the inositol monophosphatase gene $(\operatorname{suh} B)$ in some pathogenic strains. However, the inositol utilization operon GR29 was found in Cronobacter strains isolated from the environment, whilst also being absent in genomes of pathogenic strains [41]. Therefore, its role in virulence is unclear at present [42].

One of the genes of interest in this study $\operatorname{Omp} A$ reported to be involved in the basolateral invasion of the brain by $C$. sakazakii [43] was identified. The outer-membrane protein $\mathrm{A}(O m p A)$ is probably the best-characterized virulence marker of Cronobacter [44] [43]. OmpA appears to play a major role in Cronobacter invasion. In vitro, it was found that $\operatorname{Omp} A$ plays a critical role in the invasion of human intestinal epithelial cells (INT-407), Caco-2 cells and HBMECs [27] [45] [28] [43]. Invasion studies proved that $O m p A$ is crucial for 
C. sakazakii invasion of INT-407 and Caco-2 cells [42].

The second gene of interest tested was cronobacter plasminogen activator $(C P A)$ gene. There was no clear bands post electrophoresis following amplification with $C P A$ gene. Further research through plasmid sequencing is suggested. According to [42], $C P A$ along with other genes and associated putative adhesions locus are harboured on a family of RepFIB-related plasmids ( $p E S A 3$ and $p C T U 1)$ suggesting that these are common virulence plasmids. The report indicated that $98 \%$ of the 229 tested Cronobacter strains possessed these plasmids. However, the report stated that the presence of $C P A$ gene depends on species, demonstrating strong correlation with the presence of virulence traits, plasmid type and species.

\section{Conclusion}

The result of the study demonstrated the need for effective prevention and control measures as Cronobacter sakazakii constituted potential public health risks to neonates and infants. Powdered Infant Formula (PIF) is not sterile products and should be treated as a possible food safety issue for high risk population such as infants and neonates due to the presence of $C$. sakazakii.

\section{Acknowledgements}

This research was supported by the Tertiary Education Trust Fund (Institution Based Research).

\section{Conflicts of Interest}

The authors declare no conflicts of interest regarding the publication of this paper.

\section{References}

[1] Lai, K.K. (2001) Enterobacter sakazakii Infections among Neonates, Infants, Children, and Adults. Case Reports and a Review of the Literature. Medicine (Baltimore), 80, 113-122. https://doi.org/10.1097/00005792-200103000-00004

[2] Bar-Oz, B., Preminger, A., Peleg, O., Block, C. and Arad, I. (2001) Enterobacter sakazakii Infection in the Newborn. Acta Paediatrica, 90, 356-358. https://doi.org/10.1080/080352501300067857

[3] Mullane, N.R., Whyte, P., Wall, P.G., Quinn, T. and Fanning, S. (2007) Application of Pulsed-Field Gel Electrophoresis to Characterise and Trace the Prevalence of Enterobacter sakazakii in an Infant Formula Processing Facility. International Journal of Food Microbiology, 116, 73-81. https://doi.org/10.1016/j.ijfoodmicro.2006.12.036

[4] Holy, O. and Forsythe, S. (2014) Cronobacter spp. as Emerging Causes of Healthcare-Associated Infection. Journal of Hospital Infection, 86, 169-177. https://doi.org/10.1016/j.jhin.2013.09.011

[5] See, K.C., Than, H.A. and Tang, T. (2007) Enterobacter sakazakii Bacteraemia with Multiple Splenic Abscesses in a 75-Year-Old Woman: A Case Report. Age Ageing, 36, 595-596. https://doi.org/10.1093/ageing/afm092

[6] Healy, B., Cooney, S., O’Brien, S., Iversen, C., Whyte, P., Nally, J. Callanan, J.J. and 
Fanning, S. (2010) Cronobacter (Enterobacter sakazakii) an Opportunistic Foodborne Pathogen. Foodborne Pathogens and Disease, 7, 339-350. https://doi.org/10.1089/fpd.2009.0379

[7] Iversen, C., Lane, M. and Forsythe, S.J. (2004) The Growth Profile, Thermotolerance and Biofilm Formation of Enterobacter sakazakii Grown in Infant Formula Milk. Letters in Applied Microbiology, 38, 378-382. https://doi.org/10.1111/j.1472-765X.2004.01507.x

[8] Friedemann, M. (2007) Enterobacter sakazakii in Food and Beverages (Other than Infant Formula and Milk Powder). International Journal of Food Microbiology, 116, 1-10. https://doi.org/10.1016/j.ijfoodmicro.2006.12.018

[9] Kandhai, M.C., Reij, M.W., Gorris, L.G.M., Guillaume-Gentil, O. and van Schothorst, M. (2004) Occurrence of Enterobacter sakazakii in Food Production Environments and Households. The Lancet, 363, 39-40. https://doi.org/10.1016/S0140-6736(03)15169-0

[10] Zhang, H., Hou, P., Lv, H., Chen, Y., Li, X., Ren, Y., et al. (2016) Surveillance and Molecular Typing of Cronobacter spp. Commercial Powdered Infant Formula and Follow-Up Formula from 2011 to 2013 in Shandong Province, China. Journal of the Science of Food and Agriculture, 97, 2141-2146. https://doi.org/10.1002/jsfa.8021

[11] Brandão, M.L., Umeda, N.S., Jackson, E., Forsythe, S.J. and De, F.I. (2017) Isolation, Molecular and Phenotypic Characterization, and Antibiotic Susceptibility of Cronobacter spp. from Brazilian Retail Foods. Food Microbiology, 63, 129-138. https://doi.org/10.1016/j.fm.2016.11.011

[12] Gosney, M.A., Martin, M.V., Wright, A.E. and Gallagher, M. (2006) Enterobacter sakazakii in the Mouths of Stroke Patients and Its Association with Aspiration Pneumonia. European Journal of Internal Medicine, 17, 185-188. https://doi.org/10.1016/j.ejim.2005.11.010

[13] Lehner, A., Riedel, K., Eberl, L., Breeuwer, P., Diep, B. and Stephan, R. (2005) Biofilm Formation, Extracellular Polysaccharide Production, and Cell-to-Cell Signaling in Various Enterobacter sakazakii Strains: Aspects Promoting Environmental Persistence. Journal of Food Protection, 68, 2287-2294.

[14] WHO (World Health Organization) (2004) Enterobacter sakazakii and Other Microorganisms in Powdered Infant Formula: Meeting Report. http://www.fao.org/docrep/007/y5502e00.html

[15] Van Acker, J., De Smet, F., Muyldermans, G., Bougatef, A., Naessens, A. and Lauwers, S. (2001) Outbreak of Necrotizing Enterocolitis Associated with Enterobacter sakazakii in Powdered Milk Formula. Journal of Clinical Microbiology, 39, 293-297. https://doi.org/10.1128/JCM.39.1.293-297.2001

[16] Shaker, R., Osaili, T., Al-Omary, W., Jaradat, Z. and Al-Zuby, M. (2007) Isolation of Enterobacter sakazakii and Other Enterobacter sp. from Food and Food Production Environments. Food Control, 18, 1241-1245. https://doi.org/10.1016/j.foodcont.2006.07.020

[17] Mullane, N.R., O’Gaora, P., Nally, J.E., Iversen, C., Whyte, P., Wall, P.G. and Fanning, S. (2008) Molecular Analysis of the Enterobacter sakazakii O-Antigen Gene Locus. Applied and Environmental Microbiology, 74, 3783-3794. https://doi.org/10.1128/AEM.02302-07

[18] Weir, E. (2002) Powdered Infant Formula and Fatal Infection with Enterobacter sakazakii. CMAJ, 166, 1570.

[19] Farmer, J.J., Asbury, M.A., Hickman, F.W. and Brenner, D.J. (1980) The Enterobacteriaceae Study Group Enterobacter sakazakii, New Species of Entero- 
bacteriaceae Isolated from Clinical Specimens. International Journal of Systematic Bacteriology, 30, 569-584. https://doi.org/10.1099/00207713-30-3-569

[20] Joseph, S., Desai, P., Ji, Y., Cummings, C.A., Shih, R., Degoricija, L., Rico, A., Brzoska, P., Hamby, S.E., et al. (2012) Comparative Analysis of Genome Sequences Covering the Seven Cronobacter Species. PLoS ONE, 7, e49455. https://doi.org/10.1371/journal.pone.0049455

[21] Yan, X., Gurtler, J., Fratamico, P., Hu, J., Gunther, N.W., Juneja, V., et al. (2011) Comprehensive Approaches to Molecular Biomarker Discovery for Detection and Identification of Cronobacter spp. (Enterobacter sakazakii) and Salmonella spp. Applied and Environmental Microbiology, 77, 1833-1843. https://doi.org/10.1128/AEM.02374-10

[22] Forsythe, S.J., Dickins, B. and Jolley, K.A. (2014) Cronobacter, the Emergent Bacterial Pathogen Enterobacter sakazakii Comes of Age; MLST and Whole Genome Sequence Analysis. BMC Genomics, 15, Article No. 1121. https://doi.org/10.1186/1471-2164-15-1121

[23] Osaili, T. and Forsythe, S. (2009) Desiccation Resistance and Persistence of Cronobacter Species in Infant Formula. International Journal of Food Microbiolo$g y$, 136, 214-220. https://doi.org/10.1016/j.ijfoodmicro.2009.08.006

[24] Fei, P., Jiang, Y., Feng, J., Forsythe, S.J., Li, R., Zhou, Y., et al. (2017) Antibiotic and Desiccation Resistance of Cronobacter sakazakii and C. malonaticus Isolates from Powdered Infant Formula and Processing Environments. Frontiers in Microbiology, 8, 316. https://doi.org/10.3389/fmicb.2017.00316

[25] Bowen, A.B. and Braden, C.R. (2006) Invasive Enterobacter sakazakii Disease in Infants. Emerging Infectious Diseases, 12, 1185-1189. https://doi.org/10.3201/eid1208.051509

[26] Lehner, A., Tasara, T. and Stephan, R. (2004) 16S rRNA Gene Based Analysis of Enterobacter sakazakii Strains from Different Sources and Development of a PCR Assay for Identification. BMC Microbiology, 4, 43. https://doi.org/10.1186/1471-2180-4-43

[27] Nair, M.K. and Venkitanarayanan, K. (2007) Role of Bacterial OmpA and Host Cytoskeleton in the Invasion of Human Intestinal Epithelial Cells by Enterobacter sakazakii. Pediatric Research, 62, 664-669. https://doi.org/10.1203/PDR.0b013e3181587864

[28] Singamsetty, V.K., Wang, Y., Shimada, H. and Prasadarao, N.V. (2008) Outer Membrane Protein A Expression in Enterobacter sakazakii Is Required to Induce Microtubule Condensation in Human Brain Microvascular Endothelial Cells for Invasion. Microbial Pathogenesis, 45, 181-191. https://doi.org/10.1016/j.micpath.2008.05.006

[29] Fei, P., Man, C., Lou, B., Forsythe, S.J., Chai, Y., Li, R., et al. (2015) Genotyping and Source Tracking of Cronobacter sakazakii and C. malonaticus Isolates from Powdered Infant Formula and an Infant Formula Production Factory in China. Applied and Environmental Microbiology, 81, 5430-5439.

https://doi.org/10.1128/AEM.01390-15

[30] International Organization for Standardization (ISO) (2006) Milk and Milk Products: Detection of Enterobacter sakazakii. ISO/TS 22964.

[31] Pritchard, G.C., et al. (2001) Wild Rabbits: A Novel Vector for Verocytotoxigenic Escherichia coli O157. Communicable Disease and Public Health/ PHLS, 5, 74-75.

[32] Iversen, C., Mullane, N., Mccardel, B., Tall, B.D., Lehner, A., Fanning, S., et al. (2008) Cronobacter gen. nov., a New Genus to Accommodate the Biogroups of Enterobacter 
sakazakii, and Proposal of Cronobacter sakazakii gen. nov., comb. nov., Cronobacter malonaticus sp. nov., Cronobacter turicensis sp. nov., Cronobacter muytjensii sp. nov., Cronobacter dublinensis sp. nov., Cronobacter genomospecies 1, and of Three Subspecies, Cronobacter dublinensis subsp. dublinensis subsp. nov., Cronobacter dublinensis subsp. lausannnensis subsp. nov. and Cronobacter dublinensis subsp. lactaridi subsp. Nov. International Journal of Systematic and Evolutionary Microbiology, 58, 1442-1447. https://doi.org/10.1099/ijs.0.65577-0

[33] Lee, Y.D., Park, J.H. and Chang, H. (2012) Detection, Antibiotic Susceptibility and Biofilm Formation of Cronobacter spp. from Various Foods in Korea. Food Control, 2, 225-230. https://doi.org/10.1016/j.foodcont.2011.09.023

[34] Eze, A.R., Aboaba, O.O., Ifeanyi, S.T., Adetoun, F.W., Adebayo, O.E. and Moses, B. (2013) American Journal of Food and Nutrition, 3, 182-187.

[35] Aman, I.M., Esraa, M.A. and Walaa, M.E. (2016) Safety of Infant Milk Powder Sold at Kafrelsheikh Governorate Markets-Egypt. RRJVS, 2, 1-7.

[36] Mashoufi, A., Hashemi, M., Ghazvii, K., Mobarhan, M.G. and Afshari, A. (2017) Annual Research and Review in Biology, 21, 1-21. https://doi.org/10.9734/ARRB/2017/37657

[37] Craven, H.M., Mcauley, C.M., Duffy, L.L. and Fegan, N. (2010) Distribution, Prevalence and Persistence of Cronobacter (Enterobacter sakazakii) in the Nonprocessing and Processing Environments of Five Milk Powder Factories. Journal of Applied Microbiology, 109, 1044-1052. https://doi.org/10.1111/j.1365-2672.2010.04733.x

[38] Xu, X., Wu, Q., Zhang, J., Ye, Y., Yang, X. and Dong, X. (2014) Occurrence and Characterization of Cronobacter spp. Powdered Formula from Chinese Retail Markets. Foodborne Pathogens and Disease, 11, 307-312.

https://doi.org/10.1089/fpd.2013.1657

[39] Drudy, D., O’Rourke, M., Murphy, M., Mullane, N.R., O’Mahony, R., Kelly, L., et al. (2006) Characterization of a Collection of Enterobacter sakazakii Isolates from Environmental and Food Sources. International Journal of Food Microbiology, 110, 127-134. https://doi.org/10.1016/j.ijfoodmicro.2006.02.008

[40] Weiss, C., Becker, B. and Holzapfel, W. (2005) Application and Acceptability of Three Commercial Systems for Detection of Enterobacter sakazakii in Ready-to-Eat Vegetable Salads. Archiv für Lebensmittelhygiene, 56, 34-38.

[41] Grim, C.J., Kotewicz, M.L., Power, K.A., Gopinath, G., Franco, A.A., Jarvis, K.G., Yan, Q.Q., Jackson, S.A., Sathyamoorthy, V., et al. (2013) Pan-Genome Analysis of the Emerging Foodborne Pathogen Cronobacter spp. Suggests a Species-Level Bidirectional Divergence Driven by Niche Adaptation. BMC Genomics, 14, 366. https://doi.org/10.1186/1471-2164-14-366

[42] Jaradat, Z.W., Al Mousa, W., Elbetieha, A., Al Nabulsi, A. and Tall, B.D. (2014) Cronobacter spp. Opportunistic Food-Borne Pathogens. A Review of Their Virulence and Environmental-Adaptive Traits. Journal of Medical Microbiology, 63, 1023-1037. https://doi.org/10.1099/jmm.0.073742-0

[43] Kim, K., Kim, K.P., Choi, J., Lim, J.A., Lee, J., Hwang, S., et al. (2010) Outer Membrane Proteins A (OmpA) and X (OmpX) Are Essential for Basolateral Invasion of Cronobacter sakazakii. Applied and Environmental Microbiology, 76, 5188-5198. https://doi.org/10.1128/AEM.02498-09

[44] Mittal, R., Wang, Y., Hunter, C.J., Gonzalez-Gomez, I. and Prasadarao, N.V. (2009) Brain Damage in Newborn Rat Model of Eningitis by Enterobacter sakazakii: A Role for Outer Membrane Protein A. Laboratory Investigation, 89, 263-277. https://doi.org/10.1038/labinvest.2008.164 
[45] Kim, K.P. and Loessner, M.J. (2008) Enterobacter sakazakii Invasion in Human Intestinal Caco-2 Cells Requires the Host Cell Cytoskeleton and Is Enhanced by Disruption of Tight Junction. Infection and Immunity, 76, 562-570.

https://doi.org/10.1128/IAI.00937-07 